\title{
Comparative study of mud crab (Scylla serrata) fattening practices between two different systems in Bangladesh
}

\author{
M. Begum, M. M. R. Shah, Abdullah-Al Mamun and M. J. Alam \\ Bangladesh Fisheries Research Institute, Brackishwater Station, Paikgacha, Khulna-9280, Bangladesh
}

\begin{abstract}
A study was conducted to compare the survival, production and economics of mud crab fattening in cage with fattening in encircled earthen brackishwater pond. Thirty cages of $1 \mathrm{~m}(\mathrm{~L}) \times 1 \mathrm{~m}(\mathrm{~W}) \times 0.3 \mathrm{~m}(\mathrm{H})$ partitioned into 16 compartments (each $25 \times 25 \times 30 \mathrm{~cm}$ ) were set in a $40 \mathrm{~m}^{2}$ pond and another pond with same area was encircled with bamboo fence. Mud crab fattening in cage and in encircled earthen area were considered as Treatment-1 and Treatment-2, respectively with three replications each to compare the fattening system. Single adult non-gravid female crab (204.42 $\pm 2.58 \mathrm{~g})$ was stocked into each compartment of the cages and 80 crabs $(204.42 \pm 2.58 \mathrm{~g})$ were also stocked into earthen pond @ 2 indiv./ $\mathrm{m}^{2}$. The crabs were fed with chopped tilapia @ $8 \%$ of body weight twice daily. Survival rate of crab was found $93.75 \pm 6.25 \%$ and $86.12 \pm 2.16 \%$ respectively in cages and encircled earthen area. Significantly $(P<0.05)$ higher total production of crab from cages $(3.30 \pm 0.08$ $\left.\mathrm{kg} / \mathrm{m}^{2}\right)$ was recorded than the encircled earthen area $\left(0.37 \pm 0.01 \mathrm{~kg} / \mathrm{m}^{2}\right)$. Comparative benefit-cost analysis showed that bamboo cage fattening attained higher net profit (Tk 91,630.00) than crab fattening in encircled earthen area (Tk 9,345.00) from 12 crops (12-16 days per crop) fattening period. The present study revealed that mud crab fattening using bamboo cage might be better than encircled earthen area with fencing in Bangladesh.
\end{abstract}

Keywords: Mud crab, Fattening, Bamboo cage, Encircled earthen pond, Bangladesh

\section{Introduction}

Mud crab aquaculture has been practiced for many years in Southeast Asia, based primarily on capture and fattening of juvenile crabs from the wild. There is an unmet demand for mud crabs and this has led to over-exploitation in many areas. The mud crab, Scylla serrata is widely distributed in the Pacific and Indian oceans. It is available in brackish coastal waters and estuaries and has a great potential for aquaculture. Crab culture and fattening are however, still in the experimental stage in South Asia (Samarasinghe et al. 1992). Mud crab of genus Scylla, also known as green crab or mangrove crab constitute an important secondary crop in the traditional shrimp or fish culture systems in the Asian countries including Bangladesh. The importance of live mud crab as an export commodity has opened up great opportunities for crab farming. Considering the increasing demand of mud crab in the local and international markets, it has been gaining popularity among the coastal communities in greater Khulna and Chittagong regions (Azam et al. 1998).

The annual production of crab is estimated to be more than 10,000 tons (Zafar and Siddique 2000). Crab fattening is widely practiced in Thailand, Taiwan, Malaysia, Singapore, India, Indonesia and Bangladesh. Gravid female with full orange-red egg masses are in great demand in seafood restaurants of the South-east Asian countries. Due to its high price, people started to hold immature female crabs in some kind of enclosures and fed them until the gonads developed and filled the mantle cavity. In Bangladesh, coastal farmers have been practicing mud crab fattening mainly in encircled earthen ponds. In earthen ponds, some crabs manage to escape and can not be caught in time due to burrowing inside the mud. High mortality and poor survival are the main constraints of $\mathrm{crab}$ fattening in existing systems. The introduction of mud crab fattening in cages is new in our country though it has been practised in the Philippines, Indonesia, Malaysia and other South-east Asian countries. In the Philippines, only documented studies on fattening crabs were in bamboo (DA, Region VI 1988) and net cages (Kuntiyo 1992). Pens and floating cages made of bamboo, polyethylene netting and galvanized wire netting are used in coastal waters, shallow lagoons and ponds for mud crab fattening (Cholik and Hanafi 1992, Liong 1993). In Myanmar, the traditional mud crab fattening practice is done in ponds, bamboo enclosure and cage in river and canal system (Win 2000). Felix et al. (1995) reported mud crab fattening practice in cage in Vietnam. In Malaysia, floating cages $\left(6 \mathrm{~m}^{3}\right.$ with a depth of $1 \mathrm{~m}$ ) are used to fatten mud crab (Sivasubramain and Angel 1992). It is very much needed to improve fattening techniques of mud crab to get higher production in 
Bangladesh. No reliable information is available regarding the comparative study between fattening of mud crab in cage and encircled earthen pond. Therefore, the present study was undertaken to compare the survival rate, production and benefit-cost by practicing mud crab fattening in cage and encircled earthen pond.

\section{Materials and Methods}

The experiment was conducted in brackishwater ponds of Brackishwater Station of Bangladesh Fisheries Research Institute (BFRI) at Paikgacha, Khulna. The ponds were connected with tidal canal through inlet and outlet for tidal flush.

Mud crab fattening in cage and encircled earthen ponds were considered as Treatment-1 and Treatment-2, respectively to compare the fattening system.

\section{Pond preparation}

After repairing of dyke and gates, the ponds were allowed to sun and dried up to the bottom soil cracks. As per the experimental design for Treatment-2 ponds were encircled with bamboo slits made fence with an area of $40 \mathrm{~m}^{2}$ each. The bamboo slits was pushed into the mud up to $50 \mathrm{~cm}$ depth to prevent escape burrowing of crabs. Lime was applied @ $250 \mathrm{~kg} / \mathrm{ha}$ in the pond after drying. After seven days of liming, the pond was filled up (about one meter) with tidal water of the nearby the Shibsha river and after seven days cow dung was applied @ $750 \mathrm{~kg} / \mathrm{ha}$. After four days, inorganic fertilizers (TSP $25 \mathrm{~kg} / \mathrm{ha}$ and urea $20 \mathrm{~kg} / \mathrm{h}$ ) were applied.

\section{Cage preparation and setting in the pond}

For Treatment-1, ponds with the same area were prepared following the pond preparation procedure of mud crab fattening in encircled earthen area except the bamboo fencing. Thirty cages of $1 \mathrm{~m}(\mathrm{~L}) \mathrm{x}$ $1 \mathrm{~m}(\mathrm{~W}) \times 0.3 \mathrm{~m}(\mathrm{H})$ partitioned into 16 compartments (each $25 \times 25 \times 30 \mathrm{~cm}$ ) were made with bamboo slits. Each cage was provided with a lid to prevent the escape of crabs. A gap of 0.5 to $1.0 \mathrm{~cm}$ was provided between the slits at the top and sides of the cages to enable free movement of water and air through the cages but no gap was provided at the bottom to enable easy movement of the crabs. The cages were suspended in the pond with sealed plastic drums in such a way so that the cages can move up and down with the fluctuation of tide.

\section{Stocking}

Adult non gravid female crabs without broken legs or chelate were procured in good healthy conditions. After 3-4 days of applying inorganic fertilizers, stocking was done in early morning. In case of Treatment-2, the stocking density was maintained @ 20,000 crabs/ha whereas in Treatment-1, one crab was stocked in each compartment of the cages. The weight of crabs $(204.42 \pm 2.58 \mathrm{~g})$ was maintained same within the treatments.

\section{Feeding and management}

The crabs were fed twice a day with chopped tilapia @ 8\% of body weight of the stocked crab. A periodic check was made during the fattening period. Drifting seaweeds and other debris was removed to facilitate easy circulation of water and prevent damage to the cages. About $50 \%$ of water was exchanged with tidal water at every new and full moon throughout the experimental period. The pond water level was maintained within $80-100 \mathrm{~cm}$ throughout the experiment.

\section{Sampling}

In situ measurement of temperature, salinity, dissolved oxygen concentration and $\mathrm{pH}$ were carried out daily at 07:30 $\mathrm{h}$ using a thermometer, ATAGO refractometer (ATAGO Co., Ltd, Tokyo, Japan), DO meter, and a $\mathrm{pH}$ meter, respectively. After seven days onwards, checking for the development of gonad of the stocked crab was started. Gonad checking was done by placing the crabs in front of electric light or strong sun light. 


\section{Harvesting}

After the fattening period (12-16 days), all the crabs were harvested by draining out the pond water or individually caught by hand. The pincers of the crab were bound with straw or string to enable easy handling.

\section{Data Analysis}

ANOVA was done to observe any differences in growth parameters of crabs and Duncan's New Multiple Range Test (DNMRT) also employed for further analysis of the results.

\section{Results and Discussion}

The ranges of water quality parameters recorded in the experimental ponds for the duration of the experiment were: salinity: $10-18 \mathrm{ppt}$; temperature: $26-31^{\circ} \mathrm{C}$; $\mathrm{pH}$ : 7.5-8.7 and dissolved oxygen: 4.0 $7.9 \mathrm{mg} / \mathrm{l}$. These ranges were generally within acceptable levels for mud crab fattening (Cholik and Hanafi 1992).

In encircled earthen area, crabs started to be fattened after 14 days of stocking and at 16 days all the fattened crabs were harvested from the pond but in case of cage crabs started to be fattened from 10 days and finished at 12 days of stocking. So the fattening duration was shorter in cages than the encircled earthen area. In the present research, F1 category of fattened crabs was found $87.5 \%$ in cage followed by $73.75 \%$ in encircled earthen area (Table 1). At the end of the experiment, survival rate of crab was found $93.75 \pm 6.25 \%$ in cages, whereas in earthen pond it was $86.12 \pm 2.16 \%$ (Table 1). The difference of survival rate was not statistically significant. Rattanachote and Dangwatanakul (1992) observed the mud crab fattening practice in earthen pond in Surat Thani province of Thailand and reported $85.20 \%$ of survival rate and $93.77 \%$ production rate. The lower survival rate in encircled earthen pond could be due to the cannibalistic nature of mud crab. Mortality due to cannibalism has been widely documented (Iversen 1986). DA, Region VI (1988) used bamboo cage battery (with several small compartments or cubicles to accommodate a single crab per compartment) for mud crab fattening and recorded a survival of $87 \%$ which was lower than the present study. Kuntiyo (1992) showed a weight increment of 23 to $37 \mathrm{~g}$ and survival of $80-100 \%, 35$ days after stocking in net cage battery. In Vietnamese intensive farming of mud crab, the stocking density was $1-1.5 / \mathrm{m}^{2}$, achieving $1.5 \mathrm{t} /$ ha for each crop. After 4-6 months, the crabs achieved an average weight of 300-450g and fed with trash fish and molluscs. (Thach, 2004). Escritor (1972) concluded that cannibalism and the burrowing habitat of $S$. serrata should be controlled to minimize losses and to make the crab culture profitable. Survival in pond culture is generally lower as a result of cannibalism and escape (Liong 1992).

Table 1. Survival and harvest of different category crabs from fattening in cages and encircled earthen area (Values are means \pm SD of three replicates)

\begin{tabular}{|c|c|c|c|c|c|c|c|c|c|}
\hline \multirow[t]{3}{*}{ Treatments } & \multirow{3}{*}{$\begin{array}{l}\text { No of crab } \\
\text { stocked }\end{array}$} & \multirow{3}{*}{$\begin{array}{l}\text { No of crab } \\
\text { harvested }\end{array}$} & \multirow{3}{*}{$\begin{array}{c}\text { Survival } \\
(\%)\end{array}$} & \multicolumn{6}{|c|}{ Category of harvested crabs } \\
\hline & & & & \multicolumn{2}{|c|}{ F1 } & \multicolumn{2}{|c|}{$\mathrm{F} 2$} & \multicolumn{2}{|l|}{ F3 } \\
\hline & & & & Nos. & $\%$ & Nos. & $\%$ & Nos. & $\%$ \\
\hline $\mathrm{T} 1$ & $16 /$ cage $\left(1 \mathrm{~m}^{2}\right)$ & $15 \pm 1.00$ & $93.75 \pm 6.25$ & $14.33 \pm 0.57$ & $87.5 \pm 0.5$ & $1.33 \pm 0.57$ & $6.25 \pm 0.34$ & 0 & 0 \\
\hline $\mathrm{T} 2$ & $\begin{array}{l}80 \text { Nos. } / 40 \mathrm{~m}^{2} \\
\text { area }\end{array}$ & $69 \pm 1.73$ & $86.25 \pm 2.16$ & $59 \pm 1.73$ & $73.75 \pm 3.30$ & $6.33 \pm 0.57$ & $7.5 \pm 0.42$ & $4.33 \pm 0.57$ & $5 \pm 0.5$ \\
\hline
\end{tabular}

F1: Weight of individual $\mathrm{crab}>180 \mathrm{~g}$ with all the appendages unbroken.

F2: Weight of individual crab between $150 \mathrm{~g}$ to $179 \mathrm{~g}$.

F3: Weight of individual crab between $100 \mathrm{~g}$ to $149 \mathrm{~g}$. 


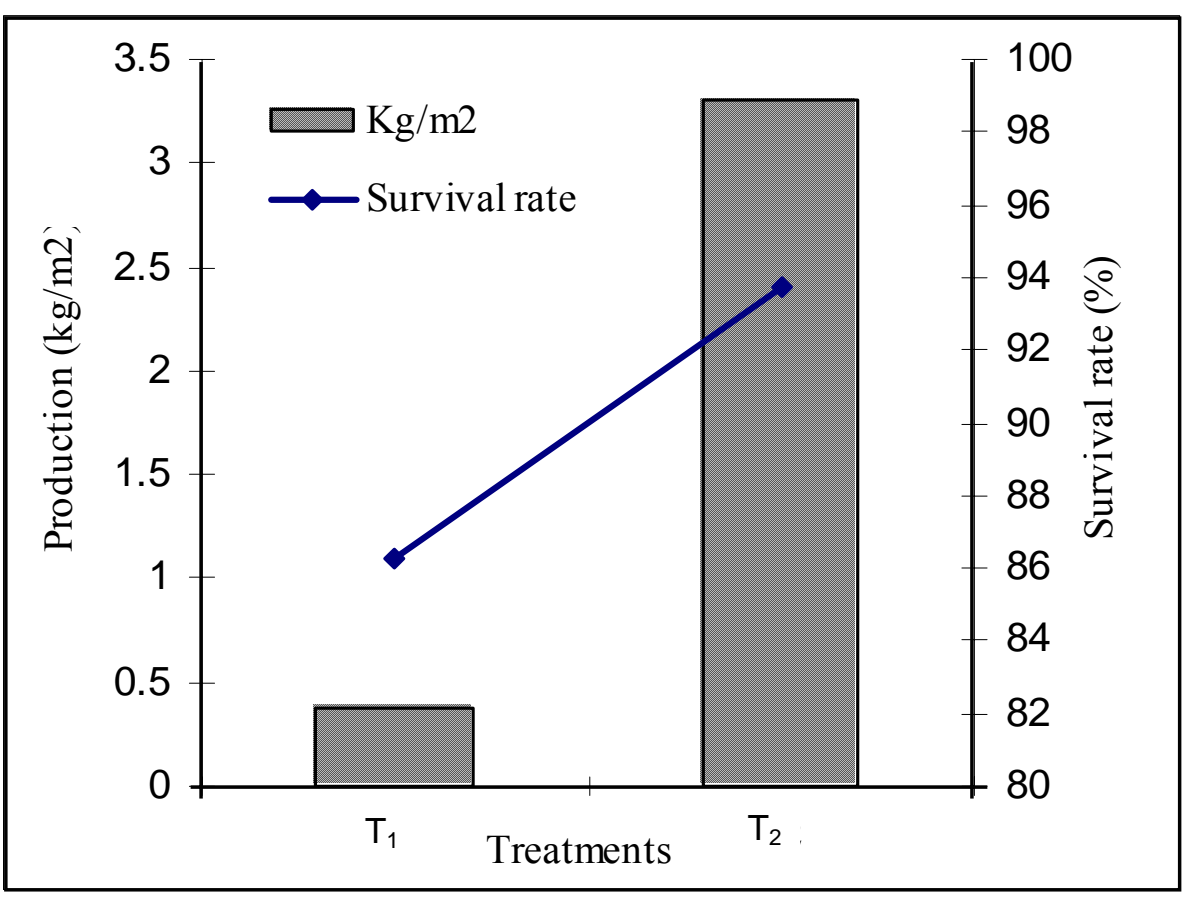

Fig.1. Production and survival rate of fattened mud crab in different treatments

Fattening of mud crab in cage shows that average weight gain was higher $(16.24 \pm 0.85 \mathrm{~g})$ than the average weight gain in earthen pond $(10.81 \pm 0.74 \mathrm{~g})$ during the fattening period (Table 2). The difference of weight gain was not statistically $(P>0.05)$ significant. Total production (F1 + F2 + F3 grade crabs) of crab from cages was found $3.30 \pm 0.08 \mathrm{~kg} / \mathrm{m}^{2}$, which was significantly $(P<0.05)$ higher than the production of encircled earthen area $\left(0.37 \pm 0.01 \mathrm{~kg} / \mathrm{m}^{2}\right)$ (Table 2). This study revealed that better survival and production can be attained in fattening by stocking the crabs individually which agrees with the result of Marichamy and Rajapaciam (2001).

Table 2. Production of fattened crabs in cages and encircled earthen area (Values are means \pm SD of three replicates)

\begin{tabular}{|l|c|c|c|c|c|c|c|}
\hline Treatments & $\begin{array}{c}\text { Initial body wt. } \\
(\mathrm{gm})\end{array}$ & $\begin{array}{c}\text { Final body wt. } \\
(\mathrm{gm})\end{array}$ & Wt. gain $(\mathrm{gm})$ & \multicolumn{3}{|c|}{ Production $\left(\mathrm{kg} / \mathrm{m}^{2}\right)$} & \multirow{2}{*}{$\begin{array}{c}\text { Total Production } \\
\left(\mathrm{kg} / \mathrm{m}^{2}\right)\end{array}$} \\
\cline { 5 - 6 } & & & $\mathrm{F} 1$ & $\mathrm{~F} 2$ & $\mathrm{~F} 3$ & \\
\hline T1 & $204.42 \pm 2.58$ & $220.66 \pm 2.08^{\mathrm{a}}$ & $16.24 \pm 0.85^{\mathrm{a}}$ & $3.08 \pm .07^{\mathrm{a}}$ & $0.22 \pm .01^{\mathrm{a}}$ & 0 & $3.30^{\mathrm{a}} \pm 0.08$ \\
\hline T2 & $204.42 \pm 2.58$ & $215.43 \pm 1.91^{\mathrm{b}}$ & $10.81 \pm 0.74^{\mathrm{b}}$ & $0.32 \pm .01^{\mathrm{b}}$ & $0.03 \pm .01^{\mathrm{b}}$ & $0.02 \pm .01$ & $0.37^{\mathrm{b}} \pm 0.01$ \\
\hline
\end{tabular}

Figures in the same column with dissimilar superscripts are significantly different $(P<0.05)$

Fattening of crab is profitable because of the fast turnover, low operating cost, high survival rate and good market demand for the end products (Liong 1992). The comparative benefit-cost analysis on 12 crops basis is shown in Table 3. In case of mud crab fattening using bamboo cage, the total production cost, total income and net profit were Tk 2,64,770.00, Tk 3,56,400.00 and Tk 91,630.00, respectively from 30 cage $\left(40 \mathrm{~m}^{2}\right.$ area) within twelve crops (12 days per crop) fattening period. In case of crab fattening in encircled earthen area, the total production cost, total income and net profit were Tk 43,645.00, Tk 53,280.00 and Tk 9,3 45.00, respectively from $40 \mathrm{~m}^{2}$ pond area within twelve crops (16 days per crop) fattening period. The benefit-cost ratio (BCR) of mud crab fattening were 1:1.35 and 1:1.21 in case of cage and earthen pond, respectively. Suceelan et al. (1995) estimated an annual net profit of Rs. 111,550 for six crops of fattening in a 0.1 ha farm (earthen pond) in Kerala backwaters. The present economic analysis revealed that mud crab fattening in cage is economically feasible and more profitable than the encircled earthen area. DA, Region VI (1988) also reported crab fattening in cages as economically viable though it requires high maintenance requirements in terms of labour (Bensam 1986). 
Table 3 Comparative benefit-cost analysis of different crab fattening methods.

\begin{tabular}{|c|c|c|c|c|c|c|c|c|c|}
\hline \multirow[t]{2}{*}{ Treatments } & \multirow[t]{2}{*}{$\begin{array}{l}\text { Area } \\
\left(\mathrm{m}^{2}\right)\end{array}$} & \multirow{2}{*}{$\begin{array}{c}\text { Produce } \\
\begin{array}{c}\text { Quantity } \\
(\mathrm{kg})\end{array}\end{array}$} & \multicolumn{2}{|c|}{ Income } & \multicolumn{4}{|c|}{ Expenditure (Tk.) } & $\begin{array}{l}\text { Net profit } \\
12 \text { crops }^{-1}\end{array}$ \\
\hline & & & $\begin{array}{l}\text { Unit } \\
\text { price } \\
\text { (Tk.) }\end{array}$ & $\begin{array}{c}\text { Total income } \\
\text { (Quantity } \times \text { unit } \\
\text { price) }\end{array}$ & Item & Quantity & Unit cost & Total cost & \multirow{12}{*}{$91,630.00$} \\
\hline \multirow{11}{*}{ Cage (T1) } & \multirow{11}{*}{40} & \multirow{11}{*}{1,188} & \multirow{11}{*}{300.00} & \multirow{11}{*}{$3,56,400.00$} & Bamboo cage & 30 nos. & $1,000.00$ & $30,000.00$ & \\
\hline & & & & & Plastic drum & 20 nos. & 100.00 & $2,000.00$ & \\
\hline & & & & & Bamboo (cage setting) & 10 nos. & 120.00 & $1,200.00$ & \\
\hline & & & & & Guard shade, gate & -- & --- & $2,000.00$ & \\
\hline & & & & & $\begin{array}{l}\text { Lime \& Fertilizers (organic+ } \\
\text { inorganic) }\end{array}$ & - & - & 200.00 & \\
\hline & & & & & Non gravid crabs (avg. 200g) & $1152 \mathrm{~kg}$. & 150.00 & $1,72,800.00$ & \\
\hline & & & & & Feed (trash fish @8\%BW) & $1383 \mathrm{~kg}$. & 40.00 & $55,320.00$ & \\
\hline & & & & & Wages & 10 days & 75.00 & 750.00 & \\
\hline & & & & & Miscellaneous & - & - & 500.00 & \\
\hline & & & & & Total cost (Tk.) & & & $2,64,770.00$ & \\
\hline & & & & & Benefit-Cost ratio (BCR) & \multicolumn{3}{|c|}{ 1:1.35 } & \\
\hline \multirow{10}{*}{$\begin{array}{l}\text { Encircled } \\
\text { earthen area } \\
\text { (T2) }\end{array}$} & \multirow{10}{*}{40} & \multirow{10}{*}{177.6} & \multirow{10}{*}{300.00} & \multirow{10}{*}{$53,280.00$} & Bamboo fence & $26 \mathrm{~m}$ & 70.00 & $1,820.00$ & \multirow{10}{*}{$9,345.00$} \\
\hline & & & & & Bamboo (fence setting) & 05 & 120.00 & 600.00 & \\
\hline & & & & & Guard shade, gate & -- & --- & $2,000.00$ & \\
\hline & & & & & $\begin{array}{l}\text { Lime \& fertilizers (organic+ } \\
\text { inorganic) }\end{array}$ & $--\cdot$ & -.- & $2,00.00$ & \\
\hline & & & & & Non gravid crabs (avg. 200g) & $192 \mathrm{~kg}$ & 150.00 & $28,800.00$ & \\
\hline & & & & & Feed (trash fish @8\%BW) & $230 \mathrm{~kg}$ & 40.00 & $9,200.00$ & \\
\hline & & & & & Wages & 7 days & 75.00 & 525.00 & \\
\hline & & & & & Miscellaneous & - & - & 500.00 & \\
\hline & & & & & Total cost (Tk.) & & & $43,645.00$ & \\
\hline & & & & & Benefit-Cost ratio (BCR) & \multicolumn{3}{|c|}{$1: 1.21$} & \\
\hline
\end{tabular}

\section{Conclusion}

From the results of this study, it may be concluded that fattening of mud crab in floating cage might be better than that of encircled earthen area. This result might be helpful to reduce the traditional fattening method and motivate the people to adopt the scientific method using bamboo made floating cages. Proper food management can minimize the predatory behaviour of mud crab. It may help the people of the coastal region to poverty alleviation through using their waterbodies by practicing this technique.

\section{References}

Azam, K., Kamal, D. and Mostofa, M. 1998. Status and potential of mud crab (Scylla serrata) in Bangladesh. In : Integrated Management of Ganges Floodplains and Sundarbans Ecosystem. M.A. Rahman,. M.S. Shah, M.G. Murtaza and M. A. Matin (eds.). Khulna Unjiversity, Bangladesh, pp. 150-160.

Bensam, P. 1986. A culture experiment on crab, Scylla serrata (Forskal) at Tuticorn during 1955-1977 to asses growth and production. In : Symposium on coastal Aquaculture. Marine Biological Association of India, India, pp. 1183-1189.

Cholik, F. and Hanafi, A. 1992. A review of the status of the mud crab (Scylla serrata) fishery and culture in Indonesia. In : The mud crab- a report of the seminar convened in Surat Thani, Thailand, November 5-8, 1991, BOBP/REP, 51: 13-27.

Department of Agriculture (DA), Region VI. 1988. Fattening mud crabs Scylla serrata in bamboo cages. Fish Extension Rep., Dept. of Agriculture, BFAR, Philippines.

Escritor, G.L. 1972. Observation on the culture of mud crab, Scylla serrata. In : Coastal aquaculture in the Indo-Pacific region. T.V.R. Pillay (ed.). West Bfleet, Fishing News Books. pp 355-361.

Felix, S., Gazendran, M. and Subramaniam, S. 1995. Aquaculture of mud crab. Seafood Export. J., 26(6):5-6

Iversen, E.S. 1986. Farming in the edge of the sea. Fishing News Books, UK. pp. 301.

Kuntiyo, A. 1992. Fattening of mud crab, Scylla serrata Forskal, in net cages installed in the drain canal of intensive prawn ponds fed with trash fish and prawn pellate. MS Thesis. University of the Philippines in the Visayas. pp. 60. 
Liong, P.C. 1992. The fattening and culture of the mud crab (Scylla serrata) in Malaysia. In : The mud crab- a report on the seminar convened in Surat Thani, Thailand, 5-8 November 1991. BOBP/REP, 51: 185-190.

Liong, P.C. 1993. The culture and fattening of crabs. INFOFISH International 3:46-49.

Marichamy, R. and Rajapackiam, S. 2001. The Aquaculture of Scylla species in India. Asian Fisheries Science, 14: $231-238$.

Rattanachote, A and Dangwatanakul, R. 1992. Mud crab (Scylla serrata Forskal) fattening in Surat Thani province. In: The mud crab. C.A. Angel (ed.). Bay of Bengal Program, Madras. India. pp. 171-177.

Samarasinghe, R.P., Fernando, D.Y. and de Silva, O.S.S.C. 1992. Pond culture of mud crab in Sri Lanka. In : The mud crab. C.A. Angel (ed.). pp 161-164. Proceedings of the seminar on mud crab in Surat Thani, Thiland, 5-8 November 1991. Bay of Bengal Programme, Madras.

Sivasubramain, $\mathrm{K}$ and Angel, C.A. 1992. A review of the culture, marketing and resources of the mud crab. In : The mud crab (ed. C.A. Angel). Bay of Bengal Program, Madras. India. pp. 5-12.

Suceelan, C., Marichamy, R., Anil, M.K. and Sathidhas, R. 1995. Mud crab culture. Technology transfer services-3, Central Marine Fisheries Research Institute, Kochi, India.

Thach, N.C. 2004. Status of marine crab culture in Vietnam. In: Mud crab aquaculture in Australia and Southeast Asia. G. Allan and D. Fielder (eds.). Proceedings of the ACIAR crab aquaculture scoping study and workshop 28-29 April 2003, Bribie Island, Australia. 56 pp.

Win, T. 2000. Myanmar country paper Director, Department of Fisheries, Ministry of livestock and Fisheries, Government of the Union of Myanmar.

Zafar, M. and Siddiqui, M.Z.H. 2000. Occurance and abundance of four Brachyuran crabs in the Chakaria Sundarban of Bangladesh. The Chittagong Univ. Journal Sci., 24 (2):105-110. 